Journal of Qualitative Criminal Justice \& Criminology

\title{
In It for the Long Haul: Exploring Gender Dynamics in Former Prisoner-Family Relationship
}

Damian J. Martinez ${ }^{1}$, Andrea Leverentz ${ }^{2}$

${ }^{1}$ California State University, Stanislaus, ${ }^{2}$ University of Massachusetts, Boston

Published on: Apr 01, 2014

DOI: $10.21428 / 88 \mathrm{de} 04 \mathrm{a} 1.99 \mathrm{a} 55 \mathrm{f} 34$

License: Creative Commons Attribution 4.0 International License (CC-BY 4.0). 


\section{ABSTRACT}

This article contributes to the growing body of literature on the role of families of origin in the reentry of former prisoners by focusing on a group of young men of color recently released from prison. Our indepth interviews with young men and selected family members highlighted the ongoing importance of their family relationships for providing important emotional and instrumental support. These relationships also are gendered. In relationships with female relatives, the former prisoners' primary role was to be there for the women in the family and thereby demonstrate their love of family and their commitment to desistance from crime, while the women provided them care, advice, and emotional support. In relationships with young male relatives, the former prisoners took a more active role, attempting to mentor the young men so they would avoid the same problems or steer their lives in a more positive direction. This article is one step in exploring how family relationships and gender dynamics function in the lives of returning prisoners.

\section{Introduction}

Researchers are beginning to pay attention to relationship dynamics within families of origin of returning prisoners (Christian \& Kennedy, 2011; Giordano, Schroeder, \& Cernkovich, 2007; Leverentz, 2011; Martinez \& Christian, 2009; Naser \& La Vigne, 2006). Male prisoners often rely on family members, particularly female family members, for emotional and financial support (Martinez \& Christian, 2009; Naser \& La Vigne, 2006). The relationship dynamics are gendered, with women more likely than men to function as caregivers within their families, regardless of whether they are the returning prisoners or the waiting family members (Codd, 2008; Leverentz, 2011). In addition, Giordano et al. (2007) highlight the importance of relationships evolving over time; one-time dysfunctional relationships may become supportive (or vice versa) as people mature and as their individual and group roles shift. Yet, researchers tend to treat the family as a singular unit without considering varying relationships and roles that people assume within their families and with different relatives, and how these differing relationships relate to desistance efforts. It is this question of varying roles and their influences that we address in this article.

We explore family dynamics through an analysis of interviews with both returning male prisoners and selected family members. In the interviews, we hope to investigate relationship-specific dynamics and how these relationships are gendered. We argue that the returning men are disproportionately the receivers of tangible and emotional supports, particularly from the women in their families. At the same time, the men provide mentoring and (mutual) support for their younger male relatives (brothers, cousins). In these relationships, they draw on their own experiences with offending and criminal justice involvement to provide advice and empathy to the other young men in their families. The finding that men are asked to just be there and show love in some way takes the place of the men's 
inability to contribute financially to the household, which clearly would be a prized contribution to the often disadvantaged households. Providing money and protection is the role that is stereotypically assigned to men, so while these relationships may be gendered in that women act as mother to the former prisoners, the men are not themselves taking on the traditional male roles within their families. At the same time, they are able to demonstrate a commitment to going straight or desisting from offending by spending time with female relatives and by mentoring young male relatives. These relationships reflect gendered dynamics within family units and illustrate some of the nuances in the ways in which the family shapes reentry and desistance from offending.

\section{Literature review}

\section{Family relationships and reentry}

One significant obstacle that former prisoners encounter upon release is their eventual return to relationships with their families. Research findings report that an individual's absence because of incarceration causes emotional suffering to the prisoner's family (Carlson \& Cervera, 1991; Christian \& Thomas, 2006; Hairston, 2001, 2003) and negatively affects the socioeconomic stability of his or her community (Clear, Rose, \& Ryder, 2001). Although many of these families are struggling with issues that might have contributed to the initial criminality/delinquency of a member (Ganem \& Agnew, 2007; Haas, Farrington, Killias, \& Sattar, 2004; Payne, Gainey, \& Carey, 2005), research has confirmed that a majority of former prisoners eventually return to and interact with their family members and rely on them for some form of support and direction (Fishman, 1986; La Vigne, Visher, \& Castro, 2004; Martinez \& Christian, 2009; Naser \& La Vigne, 2006; Naser \& Visher, 2006; Nelson \& Allen, 1999; Nurse, 2002; O’Brien, 2001).

Researchers often focus on the positive aspects of family ties in relation to the lives of returning prisoners. Family members may provide stability, social and financial support, and ties to mainstream/pro-social social life. Family ties may create regenerative power in which families reduce demands, increase capabilities, and/or change the meanings of stressors for the former prisoner (Martinez, 2006). Studies of adult prisoners indicate that support from family members is vital to their successful reintegration (Herman-Stahl, Kan, \& McKay, 2008; La Vigne et al., 2004; Martinez \& Christian, 2009; Nelson, Deess, \& Allen, 1999; Naser \& Visher, 2006; Sullivan, Mino, Nelson, \& Pope, 2002).

These relationships contribute to the accumulation of positive role interactions that minimize the amount of time, interest, and energy dedicated to criminal pathways (risks) and engagement in prosocial roles (as well as developing and maintaining associated pro-social bonds), which can curb criminal behavior (Laub \& Sampson, 1993; Piquero, Brame, \& Mazerolle, 2002; Sampson \& Laub, 1990). For example, La Vigne, Visher and Castro (2004) reported that formerly incarcerated men had high expectations of receiving family support, and that families often met-and even exceeded - the 
former prisoners' expectations. Of their original sample of 400 male participants, more than 62\% (296) of returning prisoners resided with family members upon their release. Within four to eight months, $88 \%$ resided with a family member and $92 \%$ received financial support from their family.

In a study of formerly incarcerated women, half of them resided with the family at some point during their release period, and $89 \%$ received some type of family support. In more than half of the cases, however, the formerly incarcerated women also reported problematic and sometimes abusive relationships with their mothers, though they hoped to improve these relationships (O'Brien, 2001). Also, in their metasynthesis of juvenile reentry, Martinez and Abrams (2011) found that although family members and peers can be important providers of informal social support, they can also complicate social support exchanges with undue pressure and unrealistic expectations and by offering opportunities for criminal activities. In addition, Nurse (2010) and Fader (2013) highlighted the complicated bonds that juveniles have with their families during confinement and upon release: Relationships often begin as committed, hopeful and active, but upon prolonged confinement and release, they just as often fade. In addition, many offenders have family members with histories of addiction, offending, and abuse or neglect. These studies illustrate that while family bonds can have positive aspects, the relationships also can be detrimental and often have both supportive and detrimental aspects.

One source of strain on family relationships is the offending and/or incarceration of family members, but often this is not the only or primary strain within those families. Families of prisoners may struggle with economic disadvantage, victimization within the home, and alcohol and drug abuse. For example, in the La Vigne et al. study (2004), only one-third of the participants asked their family members about employment (i.e. a form of support) and more than half had a family member with drug or alcohol problems. In the same study, $12 \%$ of male Chicago prison releasees reported being physically abused or threatened by a family or household member in the months prior to incarceration, and more than half reported drug or alcohol use by family members. In another study of female releasees in Chicago, $30 \%$ reported physical or sexual abuse by family members during childhood or adolescence, and nearly half were first exposed to drug and alcohol use by family members (Leverentz, 2011). For some former prisoners, returning to family means returning to victims or victimizers (Braman, 2004; Richie, 2001, 2002). In addition, reciprocal exchanges sometimes were expected in family relationships, so the former prisoner was expected to contribute to the household, not merely benefit from it (Martinez, 2006). Although this may be true both for male and female ex-prisoners, these reciprocal dynamics also may be gendered. Leverentz (2011) argued that even when formerly incarcerated women live with family members, the primary motivation is for the women to provide care to family members rather than merely benefiting from family support. 


\section{Gender and the family}

In many African American families, women are central to the family unit. This is characterized less by the absence of husbands and fathers than by the centrality of women. Though men may be physically present or have well-defined and culturally significant roles in the extended family, the kin unit tends to be woman-centered (Collins, 2000) and women assume many of the demands of family life. When adult men are incarcerated, the balance of power may further shift within the household, making it that much more woman-centered (Braman, 2004; Oliver \& Hairston, 2008).

Writing about women who were romantically involved with male prisoners, Comfort argued that some women acknowledged as a benefit of incarceration "the control it gave them over their households" (2008, p. 161). She quoted one woman, Jeanette, who said, "When they leave and they're gone for a long period of time an' you're used to handing your own, a woman is used to handlin' they own, the bills, everything. That's somethin' else hard, for someone to come back in, and try to run it?" (p. 161). Some of the women learned independence and self-sufficiency, and this might be disrupted by their partner's return from prison. While Comfort focuses specifically on romantic partnerships, similar dynamics and shifts may occur within the family unit more broadly.

While much of the research on delinquency, particularly male delinquency, has focused on the role of peer influences (Sutherland, 1947; Warr, 1998, 2002), Harding (2010) argued for the importance of cross-cohort socialization among young men in high-crime, high-poverty neighborhoods. In his study, young men in poor neighborhoods were more constrained in their movements and thus limited to peer networks within their neighborhoods. In addition, they sought protection by older males. These heterogeneous peer networks shaped what the younger men learned from their older male peers (e.g. learning about violence, but also about education and romantic relationships). Although Harding focused on neighborhood-based peer relationships, he argued that these relationships were viewed as family relationships for the young men, so this work also highlights the importance of peer and crosscohort socialization within a family setting. Women may be providing much of the family care in the household, but male-to-male relationships also are an important aspect of family dynamics.

Our research reveals that family relationships are central to ex-prisoners in important but complicated ways. Family members may provide support to returning ex-prisoners, but they also may expect support from the returning former prisoners, and over time, the dynamics of the relationship and the emotions tied to the relationship change (Giordano et al., 2007). In addition, these relationships are shaped by gender, age, and position within the family system. Women, particularly older women (i.e. mothers or maternal figures), often are the center of the family unit and may provide much of the care to the family. Men receive this care but also serve important roles in socialization of other men. Street and criminal networks are male-dominated; as a result, male networks may play important roles in the experiences of returning male prisoners. Although previous 
research has focused on peer influences (Scott, 2004; Warr, 1998, 2002), less attention has been given to intergenerational family influences on offending and desistance/recidivism.

This article is an exploratory analysis that builds on our existing knowledge of the complicated family relationships among returning prisoners. In it, we examine relationships between young male exprisoners and selected family members. We analyze the social dynamics of these relationships and the ways in which these relationships are gendered. Specifically, two primary types of relationships are explored: (1) those of the young men and their female relatives, including mothers, aunts, and sisters, and (2) young men and their same-generation male relatives (brothers, cousins). In both cases, we explore how they define and understand their roles within the family system. In the case of the young men, they are primarily receivers of support from their female relatives who provide the young men emotional support and information such as job leads to support their desistance and pro-social development. The young men's primary responsibilities in these relationships are to treat the women with respect and perform minor household chores. This is in contrast to traditional male roles of economic provider and breadwinner but is consistent with their economic realities and the role of women in African American households. In the second type of relationship, the young men assume the role of "professional exes" (Brown, 1991; Maruna, 2001). They attempt to provide support and guidance to their male relatives, using their experience with criminal offending and incarceration to teach important lessons of avoiding criminality, and provide empathy to other young male relatives who may face similar challenges. In return, these young male relatives also provide empathy and sympathy to the returning men in ways that most of their female relatives cannot. Our study contributes to the growing literature on family dynamics in prisoner reentry and desistance by exploring how these relationships may be gendered and the roles that each type of relationship play in the lives of returning male prisoners. It is one step toward explicating the roles family relationships play in the lives of returning prisoners.

\section{Methodology}

\section{Sampling and sample criteria}

The primary author conducted dyadic interviews with young men who recently were released from prison and with selected family members. This study used purposive sampling from a convenience group (the Illinois Going Home Program트 Evaluation Project $\stackrel{2}{2}$ ). Purposive sampling can "establish particular comparisons to illuminate the reasons for [similarities and] differences between settings or individuals" (Maxwell, 1996, pp. 71-72). These eligibility criteria, which were established by the Illinois Going Home Program Evaluation Project (and used for this study), are that individuals must

(1) be participants in or graduates of the Illinois Going Home Program; (2) be male; (3) be between the ages of 18 and 24; (4) not have been convicted of a sex-related crime; (5) have, at least initially, returned to the North Lawndale, Chicago, community; (6) have been within 60 to 90 days of release 
from prison; (7) subsequently, have been transferred to the North Lawndale adult transition center; and (8) have a family member and/or partner who resided in North Lawndale and agreed to participate in the study. The referred person need not have been in residence with the former prisoner.

The sample consisted of seven dyads: seven former prisoners and seven corresponding family members. The former prisoner selected family members who were to be interviewed. In addition to the family member interviewed, the men discussed other family relationships. The interviewees reflected the community's racial make-up; most (94\%) of the released prisoners who returned to North Lawndale were African American (La vigne \& Mamalian, 2003) and six of the seven dyads were African American (see Table 1).

Table 1. North Lawndale respondents

\begin{tabular}{|l|l|l|l|l|}
\hline & Race/ethnicity & Age & Dyadic interview & Age \\
\hline Raymond & African American & 19 & Aunt & 29 \\
\hline Jose & Mexican & 20 & Sister & 26 \\
\hline Arnold & African American & 24 & Aunt & 29 \\
\hline Chris & African American & 23 & Mother & Unknown \\
\hline Devon & African American & 26 & Aunt & 40 \\
\hline Henry & African American & 20 & Brother & 18 \\
\hline Johnny & African American & 20 & Mother & 47 \\
\hline
\end{tabular}

The criteria for selection into this study were established by the evaluation project. During team meetings of the Illinois Going Home Program Evaluation Project, we discussed all the individuals who were enrolled in the program and their progress. The former prisoners' caseworkers then determined who was eligible to be interviewed and instructed them to contact the lead author. The individuals were contacted after they had been released from the adult transition center and had completed the Illinois Going Home Program. All of the individuals who the lead author was told would contact him in fact did so. After more than year in the field, all of the people who were eligible for and willing to participate in the study had been interviewed. $\underline{4}$ 


\section{Data collection and data analysis}

The interviews were one-on-one interviews that took place between the lead author and the interview participants in a local community church or a university office. $\underline{5}$ Although one open-ended question guided discussion of family relationships ("For the next part of our discussion, I would like to ask about your family. Please describe for me, in general, what your relationships with your family are now"), the respondents discussed their families and relationships at multiple points during the interviews. These interviews were transcribed and coded, based both on a priori codes and inductive pattern coding (Miles \& Huberman, 1994). The analysis for this article focused in particular on the ways in which participants' relationships and expectations of themselves and their family members varied along gender lines. We draw both on relationships in which we interviewed both participants (e.g., a young man and his mother), as well as data in which an interview participant discusses family members whom we did not interview (e.g. that same young man's relationship with his brother). Transcripts were read in their entirety and preliminary notes were taken. The transcripts then were read again, and statements were highlighted that supported broad concepts evident across all transcripts. To improve the credibility (validity) of participants' statements, where possible, the transcripts of the former prisoners' family members were referenced for statements that addressed similar accounts of relational dynamics, thus, corroborating through triangulation (Creswell, 2007; Miles \& Huberman, 1994). The relative's description of the relationship was placed alongside the former prisoner's dialogue to show corroboration (validation) and add further detail related to their relationships.

During data analysis, we drew some conclusions by noting themes and making contrasts and comparisons (Miles \& Huberman, 1994). Specifically, we analyzed the data to determine the relationship among the codes. We (1) identified statements of former prisoners that were in the same code domain as statements of their corresponding family members, (2) identified similarities in participants' responses about a specific topic, (3) searched for common characteristics that differentiated one group of a former prisoner-family member dyad from another and (4) described the relationships based on common themes found.

\section{Findings}

The young men had varying relationships with their family members. The recruiting approach we used meant that all of the family members we interviewed had primarily strong and supportive relationships with the young men. The men, however, also spoke of other family members with whom they had both positive and strained or limited relationships. While it is important to recognize that family relationships are not inherently supportive or positive, we focus here on relationships that were generally supportive and encouraged desistance from offending. 
Family relationships are distinct from other types of relationships (e.g. romantic, peer) in that they tend to be lasting, even when the bonds go through periods of attenuation. Having a strong family bond was important to these men and their relatives, and these bonds both supported reentry efforts and were a signal of positive change. One of the main sources of variation in these relationships-and the one on which we primarily focus here-is based on how gender roles shaped relationship dynamics. Relationships with female relatives tended to be centered on a maternal and forwardfocused dynamic, whereas those with other young male relatives tended to have a mentoring dynamic. Many of the young men cited their mother or grandmother as the family member they were closest to. In contrast, many had limited or no relationship with their fathers, but often experienced and performed mentoring relationships with same-generation male relatives.

With many of these young men and their family members, there was little extra money to share and financial supports were driven primarily by situational need. Limited financial resources were common among all of the interviewees, and their expectations reflected this reality. Relatives encouraged the young men to look for work, although they also recognized the constraints they faced. In part because of the structural barriers faced by returning prisoners, they were expected primarily to be a presence in their families rather than financial providers even if the men aspired to take on these roles in the future. For example, Chris said, "It's not hard to go to my family for anything right now. But I don't want to get used to it being that way; that's why I'm out every day trying to find a job. Trying to get myself in school. Cause I don't want to be, I ain't never been, I don't like leaning on everybody else." Similarly, he emphasized "The support to give them is to give anything they need once I get right." They could also then demonstrate their commitment to the family and to going straight through these relationships, not only through signs of conventional success. For example, Arnold's aunt commented about her awareness of Arnold's need and her willingness to provide support:

Well if he needs me ... he'd come by and tell that he needed, um, money for a pack of cigarettes or that he needed ... If I had the money in my pocket, I would give him some, and sometimes he would come by, and if he had the money, he would give me money. If I needed something, like we'd order something from the restaurant or, you know, I mean, like I said, he's very generoushearted, you know. He has it, you know. Sometimes I would get money from him, you know. He came out of jail [and] I'll be like, okay, you know. He'll be like, "Most of the time I am okay, I am all right." It makes me tell, you know, “Don't go back to jail.” ... Yeah, I help him.

For Arnold's aunt, withholding financial support might mean inadvertently encouraging Arnold to return to criminal behavior to meet his material needs. At the same time, the men typically wanted to provide for themselves and their families and did so when they were able. Johnny said: 
Yeah, I help them sometimes, like with the phone bill or electricity bill, or just putting groceries in the refrigerator. I really don't need help from them. I don't ask for nothing 'cause they know I can support myself, but if I do need it, if I didn't have a job and couldn't support myself, they would help me financially.

Johnny's comments suggest that financial support is an equal familial obligation driven by need. Other young men similarly described how they contributed financially to assist their families with certain responsibilities (e.g., with bills or with food). Also, there is the tacit knowledge that if former prisoners ever needed support, at least some family members would help where possible. Because of the financial constraints among all family members, financial support was not a major component of the relationships and these dynamics were not highly gendered; men were not expected to be breadwinners in these relationships.

The young men frequently recognized that their families supported them and had limited expectations of them, at least initially. For example, Chris said, "By me just coming out of the situation I am, a lot of them [family members] like basically cater to me, trying to make sure I'm cool. They don't want me to go back down the road I went down. So they helping me as much as they can." Similarly when Jose was asked what his family expected of him, he said, "They easier on me, now they are ... I think 'cause they think it's harder for me now." Arnold said his sister "don't expect me too much. She really just tell me to take it one day at a time. Because she knows how I used to be. She really don't expect anything, so anything I do good is like a surprise for her. Really, she don't expect me to do anything, she just want me to do something different though." This is in stark contrast to the expectations on women returning from prison (Leverentz, 2011). Women are expected (and expect themselves) to return to caregiving roles in their families, suggesting that this is a gendered family dynamic, rather than one driven by the experience of incarceration alone.

\section{Maternal care: Forward-focused support}

The young men's female relatives provided similar narratives in terms of their limited expectations, particularly in terms of traditional measures of success. Johnny's mother wanted "just to know that he's trying to do better and that he wants to do better." The women in these young men's families tried to provide both emotional support and useful information to facilitate changes in their behavior and outlook. They also tended to focus on the present and future, not the young man's offending past. Partly, this reflects a focus on the man's core self and his potential (Maruna 2001). Chris's mother said, "Even through all the crap that Chris put me through, I remained his mother ... When I said I remained his mother, that means that I remained seeing him as the person he was, not the person he was acting like. I keep my focus on who Chris really was and with the help of God, that's what made me stood by him, support him, love him. I got my son back now ... He's always been a sweet, caring man." 
Jose's sister described the ways in which she helped him adjust. When he needed to go somewhere, she tried to protect him from temptation and negative peer influences, "I just tell him that if needs something that I'll do it. I'm not going to let him go by himself." In addition, she provided information and guidance:

I always give him information on different things, like when I went to the doctor. You know how they have a conflict about AIDS and all that? Well, I talk to him about it and tell him, "If you do have sex, protect yourself no matter what the girl tells you that she doesn't have anything. Just protect yourself." I talk to him about drugs, about drinking. I always give him [phone] numbers about the GED. Like I said, he called already to this place, but they told him to call back in May. I always give him the newspaper so he can go to jobs if they're available. The thing is that the only problem he has. ... Where I work at, I tried to get him in, but the first thing they ask you is, does he have a criminal record?

Jose's sister recognized the barriers and unique challenges that his criminal record posed and offered care accordingly. But, she focused primarily on what he could do in the future, and how she could foster that, rather than what he had done wrong in the past. She thereby tried to encourage positive behavior on Jose's part, not only to decrease his criminal behavior but also to improve their lives by emphasizing his strengths and his pro-social activities such as education and employment (Ward \& Maruna, 2007). His sister also thought about the future impact of their behavior on their mother's wellbeing:

He [Jose] has told me two different places to look for jobs for both of us to make money and put some money to buy a house together for my mom. Move out of here because it has a lot to do with the neighborhood, so we talk about that. He's gonna look for a good job, get his GED and get a house like in a suburb or something. We do have plans.

Although the job tips shared between Jose and his sister would benefit each of them as individuals, the primary motivation in his sister's eyes was caring for their mother. Like his sister, Jose emphasized the importance of maintaining his family ties and providing support to them. His view of social supports included: "Just being there for [my family for] anything that they need ... just to be there. ...Like you say, like love, like them, being there, caring about you, helping you ... Just talk to me and be there and stuff."

These attempts at providing care were prevalent among the young men's female relatives. Aunts and mothers worked to ease the transition of their sons or nephews from prison to the community. For example, Chris's mother explained: 
Before he came home, I had to search on the Internet and pulled up a lot of the social services that's supposed to assist inmates once they've been released, as far as placing them in jobs, assisting them with their education, furthering their education, or assisting them with housing and he's been home for three months now ... none of the programs that are supposed to assist inmates when they're released have assisted him as far as housing or anything. The schooling that he was doing while he was incarcerated, he kept it up. He finished studying, sent off for the test, took the test, and he passed it. So he's done that on his own. He is working now. I think it's fulltime, too. So he's well on his way, but no credit goes to any state facility program that's supposed to be in place for inmates that has just been released back into society.

Chris' mother emphasized that all of the support that Chris had received had been from her and the progress he had made had been through his own initiative (this is in spite of the fact that all of the young men interviewed for this article were graduates of the Illinois Going Home Program). Family members perceived programmatic and government support to be lacking and often felt the need to compensate. This increased their sense of the importance in providing the supports that the returning prisoner would not likely receive outside of family networks. Their mothers, aunts, and sisters helped the young men achieve specific goals; without their assistance, they believed, the men would be on their own.

In many cases, having generally supportive family members acted as a motivating force for former prisoners to pursue positive alternatives to crime. Arnold, whose sister "don't expect anything," still described his own role as "I feel my responsibility now is to be a man. That's my role. Do stuff and do things in the right way ... That's what I really want, give back to the community." Having family members available to consult about various issues showed former prisoners that they had the support of their family members and could rely on them for help; this encouraged dedication to the relationship (Laub \& Sampson, 2003). Even among those who were connected to reentry programs, family support was crucial.

In many instances, ex-prisoners also provided some tangible supports to their female relatives, often in the form of small chores for their relatives. For example, Raymond's aunt discussed the kinds of support that he provided to her:

The first thing he does when he comes in my house is take my garbage out. That is the first thing he do ... Without me asking ... He'll talk and say his little stuff like I said when he gets to the door, but he'll still take it out. He calls me. He's very respectful, you know. He has the key to my house, but he's not just going to come in. I told him he could come in whenever he wants to wash his clothes 'cause I have a washer and dryer. ... [As for money], why would I be asking him for money (laughing)? I am supposed to be able to give it to him. 
In many ways, Raymond's aunt remained the primary caregiver. But, she gave him a key to her house, thereby demonstrating trust in him, and he treated her with respect and did minor household chores. She hoped that in this respect, he would serve as a role model for her younger son.

In part because of their inability to reliably provide financial support to their families, a key aspect to the young men's relationships with female relatives was reestablishing emotional bonds. One of the primary ways the young men demonstrated their efforts to stay out of prison was by being a presence in the lives of their families. Another former prisoner, Devon, frequently interacted with his aunt, primarily by telephone. She described their interactions:

He always call me, though. He'll be like, "Hey auntie, how are you?" He say, "I love you." I say, "I love you, too." He say, “Well.” I say, “What you doing?" He say, “Well, I'm just up here not doing anything." I talk to him in person. I talk to him in person sometimes because [his parole officer] would bring him out to my house and I'd get to talking to him and everything.

Devon and his aunt were establishing or reestablishing an emotional bond. He took time to sit and talk with her. As with Jose, his primarily role was to be there for his family and to demonstrate his love for them by spending time with them. While their relationship was clouded by Devon's history of incarceration (e.g. being driven to his aunt's house by his parole officer), the core was based on their non-criminal connection.

He always would tell me, "Auntie, I want to braid your hair," because he loves to braid people's hair. I would let him if-see, he takes a long time on somebody's hair. He was braiding my other nephew ... he was braiding his hair, but it took him about four hours just to braid because he be ... my other nephew he has a little bit of hair. I would let him braid my hair because he would do the nice styles, but I ain't gonna sit there for all the time and get my hair done. So he was like, [Auntie] "let me braid your hair," and I told him when I could find the time to sit around, then I would let him come do it.

These interactions demonstrate the value of family relationships for many former prisoners. Family relationships are both "less disposable" than many relationships, and they also are further reaching (Giordano et al., 2007, p. 1624; Leverentz, 2011). While the criminal history is an aspect to these relationships, the bonds extend far beyond delinquent behavior.

Family members who provided support could attempt to prevent former prisoners from engaging in acts or help them avoid behaviors that could jeopardize their well-being; such relationships served as protective, caring mechanisms (Cullen, Wright, \& Chamlin, 1999; Giordano et al., 2007; Laub \& Sampson, 2003). Former prisoners were cognizant of the consequences if they did not act appropriately, but they also needed support from family members to relieve stress and supply 
methods for controlling and preventing inappropriate outbursts. This is an important and pressing concern for many former prisoners. Social support, therefore, can serve as both an intervention and a diversionary technique.

Raymond also demonstrated to his family that he was making positive progress by spending time with his aunt and grandmother. He explained:

Like my aunt and her boyfriend, he's a rapper, so he stay on the road so he be moving around. So instead of him being there, I be there to hang with her so that she doesn't feel lonely ... take her mind off of it. My grandmother, she just loves to see me being around her, just brightens up her whole day. Basically, just being around her not being into the life I was in, that just when they see me, when any of them sees me, it's like it lights up their whole day. They just feel good inside. They knew what I was capable of. They always told me you gonna be this, you gonna be that. They always complimented me, so now that I am getting older and I am growing out of the things that I was into, they can actually see me doing the things they knew I could do.

Again, the most important role that Raymond played for his aunt, who was just ten years older than he, was "just being there," and in being there, he demonstrated that he was on a positive path. The former prisoners realized that family members often were struggling with their own issues and felt it necessary to provide those family members with support. Not only did the young men's presence around their mothers, aunts, and grandmothers brighten up the day for each of them, but by being there, the young men also demonstrated that they were not involved in the life they once led.

Raymond's aunt and grandmother provided encouragement to Raymond which enforced his attempts to modify his previous behavior. Raymond's aunt had a similar view, explaining: "We talking about a lot, a lot of joking around. Talking about each other, a lot of stuff we were doing when were young. I would get mad at him at stuff he used to do as a kid, stuff like that." Being able to talk and reflect on the past served as a comfort mechanism and as a way of reinforcing positive changes. Raymond's aunt went on to say, "I say now, [our relationship] might be a little bit stronger 'cause now it's like we were close when he was younger, but now it's like we're extremely close. Now it's like we talk."

Johnny's mother similarly commented on the quality of her relationship with her son, remarking: It's getting to be considered [better than] expected. Things are well. I guess we're talking about things that I think really need to be talked about and not just overlooked and brushed under the rug. So he's coming around to opening up with me ... None of the things that's in the past-we're not talking about any of that. What we're talking about now is what he plans to do with his life from this point on, and the help that I know he needs. 
Johnny's mother emphasized that their relationship had qualitatively shifted since his release. They now had more substantive discussions, focusing on his future and not on his past. Like Chris's mother, she had similar concerns and frustrations about the lack of institutional support for the young men's attempts at reentry. She complained that his parole officer did not return her calls, and she felt that both the parole officer and Johnny could perhaps be doing more to help in his reentry to society. Many family members were frustrated by the lack of official assistance rendered to the former prisoners, and this predicament further complicated what family members could and were willing to do. The lack of communication with Johnny's parole officer also clouded their relationship due to her doubts about Johnny's efforts and fears that he was not doing as much as he could. This, too, might hint at a shifting relationship with Johnny, as they first got closer following his release and then her doubts emerged over time (see also Leverentz, 2011).

All of the relationships these young men had with their female relatives, either sisters, aunts, or mothers, had a maternal and familiar aspect for them. The women did the majority of the caregiving, and few expectations were placed on the men. The men could demonstrate their commitment to going straight by spending time with their female relatives, thereby avoiding the street. What is distinct about this relationship is that they were forward-focused; the female relatives provided support and encouragement concerning what they hoped the men would do in the future that would encourage the men to disengage (desist) from crime. This reflects their relative lack of involvement in their offending behaviors. They knew the men primarily as sons, nephews, and brothers, and less through their offending behavior. The women emphasized the men's core goodness in comparison to their prior negative behaviors. Their attentive behavior post-incarceration reinforced these roles. The men received emotional, and occasionally instrumental, support from these women with little expected in return other than being good men by showing love and affection. Women encouraged the men to search for work, but they rarely expected financial support and understood the structural constraints that made finding employment difficult. They also demonstrated a lack of faith in institutions or programs to help their sons, and so there was the increased importance of family support and guidance. They did expect the young men to provide their female relatives with respect and love. In many cases, this is all the young men could provide. Family members were primarily rewarded with the young men's presence and help with household chores rather than with economic assistance.

Relationships with female relatives sometimes were set in opposition to peer networks and, by extension, to past offending behavior. Rather, their relationships with young male relatives drew on their offending behavior, and they took on a mentorship role with the young men. In the next section, we discuss these relationships in more detail. 


\section{Redirection through mentorship}

Many of the young men had troubled childhoods. Several of the men said their mothers were addicted to drugs and one man's mother died shortly after his birth of childbirth complications; as a result, they were raised by grandmothers or other female relatives. Still, most maintained relationships with their mothers, and several reported these relationships to be strong. In contrast, few of the men had significant or positive relationships with their fathers, and, in many cases, their fathers were entirely uninvolved in their lives or left at a young age. Chris said his relationship with his father was now getting closer, although he did not know him until he was 13 years old and said that his father used to be "basically a liar." Arnold said, "My father was so caught up in the streets that it was the devil he was just teaching me. He was teaching me all the wrong things." Jose, whose father left when he was young, also witnessed his stepfather abuse his mother. Devon similarly reported abuse by both his mother and stepfather.

The lack of positive and ongoing relationships with their fathers often heightened the importance of their relationships both with female relatives and with their same generation peers. Henry, who was raised primarily by his grandmother, described his oldest brother as "the father figure to, to me growing up." Now, Henry "gotta prove myself to gain his respect back, you know, and sometimes he kinda, he speak to me in, in doubtful words in doubtful conversations." Harding (2010) emphasized the importance of cross-cohort socialization among young inner-city men. In his study, adolescent males learned about romantic and sexual relationships, education, institutional distrust, and potential for violence from slightly older adolescents in their neighborhoods. In some cases, the young men in this study took on or aspired to similar roles in the community. Arnold said, "I feel I owe a lot of people out here on these streets. A lot of these neighborhoods I owe them a lot because I took so much. I took so much from these people as far as I not only messed up my own life, I helped destroy a lot of other people's lives. Corrupt their lives. Younger guys, younger than me. I feel that I owe them a lot and it's my responsibility to give back and do something."

In many cases, the young men tried to limit their contact with their peers in an effort to stay away from trouble. Instead, they attempted to influence the lives of their younger male relatives. In these cases, they wanted their brothers and cousins to learn from their own mistakes so the relatives and brothers would not face the same problems. It is through these relationships that they were able to express generativity-a concern for future generations (Fader, 2013; Maruna, 2001; McAdams, 2006). Arnold remarked on the kind of support he provided for his cousin:

I call her [his aunt] sometimes, or she'll call me and she'll tell me about what he [his cousin] did. He out there on the streets. He caught himself not going to school today. I had to go there to check, make sure he go to school. Right now, I be calling, waking him up, making sure he go to school in the morning because I get up early. I call to make sure he go to school. If I got 
movement, I'll go over there to make sure he goes to school. I don't want to see him ... I don't want him to go through what I been through. I want to see him go a different route because he's real smart. He loves the computer. He stay on the computer. He real smart. So I want to see him do something different with his life.

Arnold's care for his cousin was apparent, although his ability to serve in this role as a positive influence was new. He said, "Because she used to tell me before, I can't tell them to do anything. How you want me to tell them stop doing this or go to school when I'm not doing it? I'm not trying, I'm on something else." These men were now well positioned to have just such an influence on the young men in their lives, for they could draw on their own experience to empathize with the choices the younger men faced. In Arnold's case, he could also attempt to influence the other men who were "trying to introduce him to the streets." He told them, "I let the guys know that's around there-because I know a lot of them, I ran with a lot of them - to let them know, you see him out here, send him to the house." In this case, Arnold provided support to his cousin because, “That's my people. I love him and I'll do anything for him." His own experiences and relationships with other men on the street put him in a position to have a positive influence on his cousin.

As with Arnold's aunt, Jose's sister sought out Jose to be a positive and empathetic influence on her son. She said, "I see my brother in my son, you know? Like, at that age, that's when he started hanging around little boys. I have a son, and I don't want him to go through things that my brother been through." She went on to say, "He was talking to my little brother: 'It's not good to be locked up. You know what I been through. You know how life's turned out for me. I don't want that for you.' And he told me that he wouldn't like his little brother to be like him. He knows that he's responsible for them right now."

The young men shared experiences with male relatives who were situated similarly. Henry and his brother talked about their attempts to find work. Both brothers had a similar view of their relationship and the role it served. Henry said:

We almost make the same decisions sometimes, and then sometimes he'll make a better decision than me or I'll make a better decision than him. So I always take his input on the situation because he always had been there to help me with stuff like that.

His brother framed their discussions in terms of their mutual attempt to find work:

[We] say what's been going on, what we been doing, where we gonna go try and find a job at, talk to people who already working, and see if they can try to get us on where they at. It's just really everyday things. Really our main subject every day is getting a job. That's the main thing we really talk about or discuss, is a job. 
Though Henry and his brother emphasized different aspects of their relationship, a common thread was the mutuality of their experience. Female relatives often shared a history with the men, but their lives typically were distinct enough that they were not "making the same decisions" or following similar paths. In contrast, Henry and his brother empathized with one another through their shared experiences with making bad choices - the draw of the street and the struggles to make the right decisions. Henry described his brother as a close friend:

Like if I'm going through emotional problems, I'll call my brother first because he'll give me another way to look at it or he'll try to say, "I understand." He understand what I be going through at times, you know. Sometimes I feel like my brother the reason why I want to change my life around, or turn my life around. Because the things that we been through already. ... There things that I done toward him that I probably wouldn't have accepted if he'd done toward me. And he's still there for me. He really care about me. It ain't about what I got on or how I act, you know. I can be myself around my brother, you know. So I feel like, I mean, that's the realest friend I ever had, and I don't ever want to lose him. That's how I feel about my brother. That's the only friend, the realest friend I ever had.

Henry referred to their long-lasting relationship, their shared hardships, and the depth of their relationship. His brother was his "realest friend" who was not concerned with superficiality, and through the strength of their relationship, his brother inspired Henry to change his behavior. Henry went on to detail the ways in which his brother encouraged better decision-making through concrete actions.

Because, I mean, he the type that if you doing something that you know you ain't supposed to be doing, but you trying to play it off like you supposed to be doing it, then he tell you, "You in the wrong. Like, man, what is you doing? You know you don't supposed to be doing that. That's not right, you know." He don't sugarcoat nothing, you know. He tell you flat out how it is. Either you gonna accept it or not, but, I mean ... You think about it and you be mad at first thing because you think you're doing right, but then you'll think about it like, man, you right. You right on, I shouldn't even be up here.

Like one day I was talking to just one of my old friends by my house-he lived like two blocks [away]. And we standing there talking, you know, the whole time I didn't know he was hustling. And I'm just talking to him, having a nice conversation. My brother done rolled up like, "You know you ain't supposed to be on this corner with this boy." I'm like, "He ain't doing nothing; he just standing right here." He's like, “Let me get a bag, yo." Out his pocket he pull out, and I'm like, "Man, you too crazy." I go jump in the car, and he's like, "Yeah, I told you those guys is doing something. We pulled off and I was like, "Yeah, man, I didn't know. I thought he was just standing 
out there because he told me he wasn't doing nothing. But my brother, he like try to look out for me the same way I try to look out for him.

Henry described in detail the mechanisms through which his brother provided him with support and how much that support meant to him. In this example, Henry's brother went far beyond abstract emotional support. He told Henry when he was wrong, and because of their relationship, Henry heard this criticism-and intervened.

Doubtless, imprisonment was a debilitating and discouraging experience for the former prisoners, but its impact on family members was explained by Henry's brother:

I know that he feel like he got a felony and it's just no hope for him no more, but I be telling him, man, you smart. ... I always try to encourage him to go on ahead and do the right thing. He just feel like since he got this felony, he had put in over two-hundred applications since he been out, [and] ain't nobody called him. He's trying to get in this program. He's trying to see what's going on with that, living with the grandmother and try to avoid situations and problems that she's giving him, then that girlfriend and all that. Sometimes it frustrates you when you do so much and get back so little.

Henry's brother's similar positionality allowed him to empathize with Henry's struggles in ways that others cannot as fully. In the same way that Arnold was trying to encourage positive and non-criminal decision-making on the part of his cousin, Henry's brother was trying to encourage the same sorts of decisions in Henry.

In contrast with their relationships with female relatives, who were much less likely to have the same criminal histories, the young men assumed mentoring or mutually supportive relationships with their male relatives. Fader (2013) noted that this parallels the relationships that many of the young men had with male peers; they shared first-hand experiences both with street life and with the consequences of those choices. Henry and his brother shared much of their history and present struggles. Arnold could anticipate the challenges his younger cousin might face and tried to encourage a different path. Within these relationships, they could take on a quasi-professional ex role (Brown, 1991; Maruna, 2001). Their past offending histories were central to the present relationships, because it is these experiences that ground the mentoring. They both tried to influence younger boys or provide empathy and support to their same aged peers.

\section{Discussion and conclusion}

The relationships highlighted in this article are the positive familial relationships that these young men had. This is a function of the methodology but also highlights the strengths and variation in these relationships. The young men highlighted the importance of their family relationships in their 
changing sense of self and in their plans for going forward. Family bonds were both more meaningful and lasting and also more supportive than peer relationships. These relationships also experienced shifting dynamics in a particularly acute way, as the men navigated their release from prison. Indeed, several of the men and their relatives highlighted that merely interacting with family was a sign that their lives were on a positive path forward. Positive relationships were not universal in these young men's lives, and as a result, they were not taken for granted.

The relationships of the men with their family members were shaped by the gendered nature of their roles in their families. Female relatives served a maternal care-giving function, in which the women provided support (primarily emotional, but also sometimes instrumental or financial) and the men demonstrated love and attention. This is consistent with research on the care-giving roles that Black women, in particular, take on in both family and community (Collins, 2000; Leverentz, 2011) and is exacerbated by structural disadvantages, including mass incarceration (Braman, 2004; Comfort, 2008; Martinez \& Christian, 2009). Women have strong roles within the family, and the families recognize the structural barriers to traditional masculine roles that young men of color face, particularly those with a criminal record. The young men's criminal pasts were downplayed in these relationships. They were not ignored, but neither were they the central feature of the relationship. Instead, the women took a future-focused approach, in which the young men could (and should) prove that they were on a new path by giving attention and affection to their families.

In contrast, the temptations of the street, the struggles of being a young urban male of color, and criminal pasts play a central role in the relationships the young men had with young male relatives. In these relationships, the men took on a mentoring relationship with other young male relatives. The men could empathize with one another over shared struggles and experiences, and they could serve as positive role models as they were going straight and making positive decisions. Young men with one another served as informal professional exes; their offending pasts (and, more broadly, their experience of inner-city young men of color) were reframed to serve the positive function of demonstrating the possibility of positive change to other male relatives (Brown, 1991; Maruna, 2001; Maruna and Roy, 2007). The gender dynamics of both the family and the street continued to shape the young men's relationships with family members as they returned to the community, and as they attempted to make positive changes in their lives.

\section{Limitations}

In qualitative research, there is frequently a concern about sample size, particularly that not having a larger sample prevents the reader from being able to assess whether certain patterns in the data are analytically important, or whether they would have changed had more participants been interviewed. We recognize that our sample size necessitates cautionary qualifications to our conclusions, but, like qualitative researchers before us who have relied upon small samples (e.g. Christian \& Kennedy, 2012; 
Gadd \& Farrall, 2004; Jacques \& Wright, 2008; Steffensmeier \& Ulmer, 2005); our analysis is exploratory in nature and focuses on developing concepts, rather than testing hypotheses. This sample is not representative of the total incarcerated population in Illinois and is a select group, but the sampling strategy of these dyadic interviews allows us to begin to understand family dynamics among prisoners. As Miles and Huberman (1994) argued, "We are generalizing from one case to the next on the basis of a match to the underlying theory, not to a larger universe. The choice of cases usually is made on conceptual grounds, not on representative grounds" (p. 29). As Piquero, Farrington, and Blumstein (2007) noted in their examination of criminal careers, qualitative research enhances inferences stemming from quantitative research, whether refining or complementing what is known about onset, intermittency, and desistance. While we were limited by the constraints of the program evaluation framing this data collection, the information provided and the findings indicated provide sufficient insight for the study's purpose: to explore gender dynamics among select former prisoners and their family members. We hope that future research further explores and tests the concepts developed here.

\section{Future considerations and directions}

This analysis is based on a small number of dyadic interviews with young men released from state prison facilities to select neighborhoods in Chicago and selected relatives. We must therefore exercise caution in generalizing these findings. However, our research provides one step in understanding the ways in which family relationships and dynamics are shaped by individual relationships that are influenced by gender dynamics within the family unit. This article provides a base for a more extensive data collection and analysis on gendered dynamics within families of returning exprisoners. It contributes to a growing literature in this area while also suggesting fruitful directions for future research (Christian \& Kennedy, 2011; Giordano et al., 2007; Leverentz, 2011; Martinez \& Christian, 2009).

We emphasize the gender differences in family relationships found in this research. Women are socialized to be caregivers and even more so in the highly disadvantaged circumstances in which these families find themselves. Race, class, and mass incarceration all shape these family dynamics (Braman, 2004; Comfort, 2008; Oliver \& Hairston, 2008). In addition, these patterns reflect gendered patterns of offending and involvement in street life. The women, even those of the same generation of these young men, tended to avoid sharing past experiences in ways that lent themselves to mentoring relationships that the men had with their male relatives (Harding, 2010; Maher \& Daly, 1996; Maher \& Hudson, 2007; Miller, 1995, 1998). Even among women with a criminal or incarceration history, the gender dynamics of street life may inhibit the extent to which there is cross-gender mentoring within families. Given the constraints of this sample, in which no women interviewed had this history, this remains an open and important question. Might we see professional ex mentoring relationships between mixed gender relatives, or do gendered family and street dynamics hinder this even in the 
context of shared offending histories (Leverentz, 2011)? How do impoverished women coping with the incarceration of male family members manage to be so resilient as to maintain a forward focus? In addition, while we recognize the potentially destructive nature of some family relationships, we are unable to address them here. This is another area worthy of further research, in terms of how returning prisoners navigate those relationships and how they shape their ability to desist or return to offending.

\section{References}

Braman, D. (2004). Doing time on the outside: Incarceration and family life in urban America. Ann Arbor, MI: University of Michigan Press.

Brown, J. D. (1991). The professional ex-: An alternative for exiting the deviant career. Sociological Quarterly, 32, 219-230.

Carlson, B. E., \& Cervera, N. J. (1991). Incarceration, coping, and support. Social Work, 36, 279-285.

Christian, J. \& Kennedy, L.W. (2011). Secondary Narratives in the Aftermath of Crime: Family Members' Relationships with Prisoners. Punishment and Society, 13, 379-402.

Christian, J., Mellow, J., \& Thomas, S. (2006). Social and economic implications of family connections to prisoners. Journal of Criminal Justice, 34, 443-452.

Clear, T. R., Rose, D. R., \& Ryder, J. A. (2001). Incarceration and the community: The problem of removing and returning offenders. Crime \& Delinquency, 47, 335- 351.

Codd, H. (2008). In the shadow of prison: Families, imprisonment, and criminal justice. Cullompton, Devon, United Kingdom: Willan Publishing.

Collins, P. H. (2000). Black feminist thought: Knowledge, consciousness, and the politics of empowerment. New York, NY: Routledge.

Comfort, M. (2008). Doing time together: Love and family in the shadow of the prison. Chicago, IL: University of Chicago Press.

Creswell, J. W. (2007). Qualitative inquiry and research design: Choosing among five approaches (2nd ed.). Thousand Oaks, CA: Sage Publications.

Cullen, F. T., Wright, J. P., \& Chamlin, M. B. (1999). Social support and social reform: A progressive crime control agenda. Crime \& Delinquency, 45, 188-207.

Fader, J. (2013). Falling back: Incarceration and transitions to adulthood among urban youth. New Brunswick, NJ: Rutgers University Press. 
Fishman, L. T. (1986). Repeating the cycle of hard living and crime: Wives' accommodations to husbands' parole performance. Federal Probation, 50, 44-54.

Gadd, D., \& Farrall, S. (2004). Criminal careers, desistance and subjectivity: Interpreting men's narratives of change. Theoretical Criminology,8, 123-156.

Ganem, N. M., \& Agnew, R. (2007). Parenthood and adult criminal offending: The importance of relationship quality. Journal of Criminal Justice, 35, 630-643.

Giordano, P. C., Schroeder, R. D., \& Cernkovich, S. A. (2007). Emotions and crime over the life course: A neo-median perspective on criminal continuity and change. American Journal of Sociology, 112, 1603- 1661.

Haas, H., Farrington, D. P., Killias, M., \& Sattar, G. (2004). The impact of different family configurations on delinquency. British Journal of Criminology, 44, 520-532.

Hairston, C. F. (2001). Fathers in prison: Responsible fatherhood and responsible public policies. Marriage and Family Review, 32, 111-135.

Hairston, C. F. (2003). Prisoners and their families: Parenting issues during incarceration. In J. Travis \& M. Waul (Eds.), Prisoners once removed: The impact of incarceration and reentry on children, families, and communities (pp. 259-282). Washington, DC: The Urban Institute Press.

Harding, D. J. (2010). Living the drama: Community, conflict, and culture among inner-city boys. Chicago, IL: University of Chicago Press.

Herman-Stahl, M., Kan, M. L., \& McKay, T. (2008). Incarceration and the family: A review of reseaerch and promising approaches for serving fathers and families. Washington, DC: U.S. Department of Health and Human Services.

Jacques, S., \& Wright, R. (2008). The victimization-termination link. Criminology, 46, 1009-1038.

Laub, J. H., \& Sampson, R. J. (2003). Shared beginnings, divergent lives: Delinquent boys to Age 70. Cambridge, MA: Harvard University Press.

La vigne, N. G., \& Mamalian, C. A. (with J. Travis \& C. visher). (2003). A portrait of prisoner reentry in Illinois. Washington, DC: Urban Institute.

La vigne, N. G., visher, C., \& Castro, J. (2004). Chicago prisoners' experiences returning home. Washington, DC: Urban Institute.

Leverentz, A. (2011). Being a good daughter and sister: Families of origin in the reentry of African American female ex-prisoners. Feminist Criminology 6, 239-267. 
Lynch, M. (2000). Rehabilitation as rhetoric: The ideal of reformation in contemporary parole discourse and practices. Punishment and Society, 2, 40-65.

Maher, L., \& Daly, K. (1996). Women in the street-level drug economy: Continuity or change? Criminology, 34, 465-491.

Maher, L., \& Hudson, S. L. (2007). Women in the drug economy: A metasynthesis of the qualitative literature. Journal of Drug Issue, 37, 805-826.

Martinez, D. J. (2006). Informal helping mechanisms: Conceptual issues in family support of reentry of former prisoners. Journal of Offender Rehabilitation, 44, 23-37.

Martinez, D. J., \& Abrams, L. S. (2011). Informal social support among returning young offenders: A meta-synthesis of the literature. International Journal of Offender Therapy and Comparative Criminology, $57,169-190$.

Martinez, D. J., \& Christian, J. (2009). The familial relationships of former prisoners: Examining the link between residence and informal support mechanisms. Journal of Contemporary ethnography, 38, 201-224.

Maruna, S. (2001). Making good: How ex-convicts reform and rebuild their lives. Washington, DC: American Psychological Association.

Maruna, S., \& Roy, K. (2007). Amputation or reconstruction? Notes on the concept of "knifing off" and desistance from crime." Journal of Contemporary Criminal Justice, 23, 104-124.

Maxwell, J. A. (1996). Qualitative research design: An interactive approach. In Bickman \& D. J. Rog (Series Eds.), Applied social research methods series: vol. 4. Thousand Oaks, CA: Sage Publications.

Miles, M. B., \& Huberman, A. M. (1994). Qualitative data analysis: An expanded sourcebook. Thousand Oaks, CA: Sage Publications.

Miller, J. (1995). Gender and power in the streets: Street prostituion in the era of crack cocaine. Journal of Contemporary ethnography, 23, 427- 452.

Miller, J. (1998). Up it up: Gender and the accomplishment of street robbery. Criminology, 36, 37-66.

Naser, R. L., \& La vigne, N. G. (2006). Family support in the prisoner reentry process: Expectations and realities. Journal of Offender Rehabilitation, 43, 93-106.

Naser, R. L., \& visher, C.A. (2006). Family members' experiences with incarceration and reentry. Western Criminology Review, 7, 20-31. 
Nelson, M., Deess, P., \& Allen, C. (1999). The first month out: Post-incarceration experiences in New York City. New York, NY: Vera Institute of Justice.

Nurse, A. M. (2002). Fatherhood arrested: Parenting from within the juvenile justice system. Nashville, TN: vanderbilt University Press.

Nurse, A. M. (2010). Locked up, locked out: Young men in the juvenile justice system. Nashville, TN: vanderbilt University Press.

O'Brien, P. (2001). Making it in the "free world": Women in transition from prison. Albany, NY: State University of New York Press.

Ogloff, J. R. P., \& Davis, M. R. (2004). Advances in offender assessment and rehabilitation: Contributions of the risk-needs-responsivity approach. Psychology, Crime $\mathcal{E}$ Law, 10, 229-242.

Oliver, W., \& Hairston, C. F. (2008). Intimate partner violence during the transition from prison to the community: Perspectives of incarcerated African American men. Journal of Aggression, Maltreatment $\mathcal{E}$ Trauma, 16, 258-276.

Payne, B. K., Gainey, R. R., \& Carey, C. S. (2005). All in the family: Gender, family crimes, and later criminality. Women \& Criminal Justice, 16, 73-89.

Piquero, A. R., Brame, R., \& Mazerolle, P. (2002). Crime in emerging adulthood. Criminology, 40, 137170.

Piquero, A.R., Farrington, D., \& Blumstein, A. (2007). Key issues in criminal career research: New analyses of the Cambridge study in delinquent development. Cambridge, MA: Cambridge University Press.

Richie, B. E. (2001). Challenges incarcerated women face as they return to their communities: Findings from life history interviews." Crime \& Delinquency, 47, 368-389.

Richie, B. E. (2002). The social impact of mass incarceration on women. In M. Mauer \& M. ChesneyLind (Eds.), Invisible punishment: The collateral consequences of mass incarceration (need page numbers here). New York, NY: New Press.

Safer Foundation. (2010). In Services at the adult transition centers. Retrieved January 21, 2012, from http://www.saferfoundation.org/services-programs/services

Sampson, R., \& Laub, J. (1993). Crime in the making: Pathways and turning points through life. Cambridge, MA: Harvard University Press. 
Scott, G. (2004). "It's a sucker's outfit": How urban gangs enable and impede the reintegration of exconvicts. ethnography, 5, 107-140.

Steffensmeier, D. J., \& Ulmer, J. T. (2005). Confessions of a dying thief: Understanding criminal careers and illegal enterprises. New Brunswick, NJ: Transaction.

Sullivan, E., Mino, M., Nelson, K., \& Pope, J. (2002). Families as a resource in recovery from drug abuse: An evaluation of La Bodega de la Familia. New York, NY: vera Institute of Justice.

Sutherland, E. H. (1947). Criminology (4th ed.). Philadelphia, PA: Lippincott.

Ward, T., \& Maruna, S. (2007). Rehabilitation. New York, NY: Routledge.

Warr, M. (1998). Life-course transitions and desistance from crime. Criminology, 36, 183-216.

Warr, M. (2002). Companions in crime: Social aspects of criminal conduct. Cambridge, UK: Cambridge University Press.

\section{Contributors}

Damian J. Martinez is Assistant Professor in the Department of Criminal Justice at California State University, Stanislaus, USA. His research interests include desistance from crime, and prisoner reentry and reintegration. His recent publications have appeared in the International Journal of Offender Therapy and Comparative Criminology, Probation Journal, Journal of Contemporary ethnography, and Journal of Offender Rehabilitation. Dr. Martinez also is co-editor of How Offenders Transform Their Lives.

Andrea Leverentz is Associate Professor in the Department of Sociology at the University of Massachusetts Boston. Her current research interests include the impacts of crime on communities, how individuals and communities perceive crime, prisoner reentry, and women's experiences with crime and criminal justice. Her work has appeared in Sociological Forum, Feminist Criminology, Journal of Contemporary Ethnography, Punishment and Society, and Journal of Research in Crime and Delinquency. Dr. Leverentz is the author of The Ex-Prisoner's Dilemma: How Women Negotiate Competing Narratives of Reentry and Desistance.

\section{Footnotes}

1. This is a comprehensive program designed to assist individuals released from Illinois prisons by leveraging existing services in the community.

2. This evaluation project sampled males released from the Illinois Department of Corrections Westside Adult Transition Center, a minimum-security residential transition center where 
individuals were (supposed to be) required to participate in non-institutional employment, education, life skills training, and/or community service, as well as institutional responsibilities, for a minimum of 35 hours per week (Safer Foundation, 2010). $\doteq$

3. Individuals who were incarcerated in an Illinois state prison and who were scheduled to be released within two years and are classified as minimum risk may be transferred to adult transition centers (La Vigne and Mamalian, 2003).

4. Since this research originated as an evaluation study, we were constrained by the program's requirements and timeline. While we had envisioned and would have preferred to continue enrolling participants in order to have more variety in the family members selected-e.g. more people who were not mothers or aunts, and especially some fathers-the fact that who our research participants referred, and who they talked about in the interviews, demonstrates the gendered nature of these family relationships, and who these young men identify as key supports. $\bullet$

5.

Each member of the dyad was interviewed separately. 